park as a breeding bird. This was the smallest of the colonies discovered.

Forster's Terns were recorded nesting in the "Turtle Marshes" on the south side of Dauphin Lake, two miles upstream from the mouth of the Turtle River. This colony was visited on July 13,1971 and at this time contained several young of which at least 15 were too small to fly. The number of adults was estimated to be 60 .

There are several factors limiting the breeding distribution of Forster's Tern in the Interlake, of which food supply may well be the most important. Many of the water bodies in the Interlake are infertile, and, as a result, animal life in the form of minnows, aquatic insects, dragonflies, etc. is limited. As these are staple foods of Forster's Tern, the number of breeding terns is small. There is a lack of marshes with moderately dense stands of bulrush, cattail, or bur-reed (Sparganium) for nesting cover. Marshes with both good nesting habitat and an abundant food source are scarce in the Interlake, although some of the marshes bordering lakes Winnipeg and Manitoba are exceptions. Lake Winnipeg is the eastern border of the breeding range of this species. East of this lake the habitat is boreal, and marshes are replaced by bogs surrounded by forest.

\section{Acknowledgments}

I wish to thank George Cotter and Martin McNicholl for the use of their data.

\section{LITERATURE CITED}

Gerrard, J. M., and D. W. A. Whitfield. 1971. Breeding distribution of Forster's Tern in the Prairie Provinces. Blue Jay, 29:19-22.

McNicholl, M. K. 1971. The breeding biology and ecology of Forster's Tern (Sterna forsteri) at Delta, Manitoba. Un published M.Sc. thesis, University of Manitoba. $652 \mathrm{pp}$.

Soper, J. D. 1953. Birds of Riding Mountain National Park, Manitoba, Canada. Can. Wildl. Serv., Wildl. Mgt. Bulletin, Series 2, Number $6,54 \mathrm{pp}$.

\title{
CATBIRD AT CHURCHILL, MANITOBA
}

\section{by R. Barry Ranford, 1345 Kendall Road, Mississauga, Ontario and}

\section{Mrs. Linda McKeane, 5 Sherwood Avenue, Toronto 12, Ontario}

While on a bird-watching and photographic trip to Churchill this spring, we had the good fortune to find a pair of nesting Pigeon Hawks (Falco columbarius) in a small spruce grove across from the Northern Lights Observatory east of Fort Churchill. We spent several days photographing these hawks and it was during this time on June 18, 1971 that a Catbird (Dumetelia carolinensis) was first heard and later seen.

It was about 10:00 a.m. and slightly overcast when we heard a distinctive cat-like mewing. Minutes later the bird appeared at the foot of a spruce tree about, 15 feet away from us. We could clearly see the blackish cap and rusty undertail coverts on this slate grey bird. It remained in the open for several minutes before moving out of sight. However, during that day we heard it calling frequently and saw it again on four or five occasions in the same area. As both of us are from southern Ontaric where Catbirds are a common breeding species, there could be no doubt in our minds as to the bird's identity.

According to Jehl and Smith (Birds of the Churchill region, Manitoba. Manitoba Museum of Man \& Nature, Spec. Publ. No. 1, Winnipeg, 1970) the Catbird has not previously been recorded at Churchill. However, two residents of Churchill, Angus and Berenice McIver, mentioned seeing a Catbird near Churchill about 15 years ago. That bird was at Herriot Creek, which flows into the Churchill River about 20 miles south of the town of Churchill.

Godfrey (The birds of Canada. Natl. Mus. Can. Bull. 203, 1966) notes the accidental occurrence of the Catbird north to Lesser Slave Lake. 